\title{
Deciding to migrate: Stories of African immigrant women living in New Zealand
}

\author{
Adesayo Adelowo', Liz Smythe ${ }^{2}$ and Camille Nakhid ${ }^{2}$
}

${ }^{1}$ Manukau Institute of
Technology, New Zealand
${ }^{2}$ Auckland University of
Technology, New Zealand
AOTEAROA

NEW ZEALAND SOCIAL

WORK 28(1), 52-59.

CORRESPONDENCE TO:

Adesayo Adelowo adesayo.adelowo@ manukau.ac.nz

\begin{abstract}
INTRODUCTION: With migratory movements of people increasing worldwide cultural competence is becoming a key social work capability. One aspect of cultural competence includes an appreciative understanding of new migrants reasons for migration. The immigration of black African people to New Zealand is a relatively recent phenomenon because, historically, immigration policy favoured people of British origin. This article aims to explore the experiences and motivations of black African women who were recent migrants to New Zealand.
\end{abstract}

METHOD: The study used a purposive sample of 15 black African women migrants aged between 21 and 60 years. The women were all recent migrants from Africa having resided in New Zealand for a period of between one and five years. Data was collected using semistructured interviews and a narrative methodology based on Africentric philosophy.

FINDINGS: For most of the women in the study migration was a positive choice made in order to secure educational and career opportunities for themselves and their children. For some there were also push factors in the form of political and economic instability in their countries of origin. Relationships with family and friends already living in New Zealand were also significant motivational factors.

CONCLUSION: Social workers in New Zealand need an appreciative understanding of the culture and history of new migrants, but also of their aspirations and motivations for setting out on an epic journey for them and their families. This article offers insights into the motivations and aspirations of a group of recent black African women migrants, and challenges some common assumptions.

KEYWORDS: migration; narrative methods; African people; women; cultural competence

\section{Introduction}

Until the lions have their historians the tales of hunting will always glorify the hunter. (African proverb)

Migration has been a recurrent phenomenon since the beginning of human existence, and always involves migrants, and their families, in a major life transition. In recent times, migration has been viewed by the
New Zealand government as a positive phenomenon facilitating economic growth, and counteracting the adverse effects of an aging population (Fletcher, 1999; Henderson, 2004). A review of relevant literature reflects a lack of research on the experiences of African women immigrating to New Zealand.

Immigrant women from all parts of the world are usually categorised as a homogenous group. Traditionally, women are seen as 
family dependants that migrate only to join their husbands. An almost exclusive focus on low-wage female migrants reflects a commonly held stereotype and fails to acknowledge the experience of highly skilled African women who migrate for their own reasons (Ngo, 1994; Reynolds, 2006). It is important to understand why African women choose to migrate to New Zealand and this paper intends to make a contribution towards answering that question.

The factors that motivate people to migrate include: educational opportunities, economic reasons and political exile. For the process of migration to be fully understood, personal, familial, social and cultural factors have to be taken into account (Bhugra, 2003). From a historical point of view cultural and economic factors have always been influential with regards to those allowed to migrate to New Zealand. Those who were encouraged to migrate were expected to adapt to life in New Zealand without difficulty. To achieve this goal, the Immigration Restriction Act 1899 was put in place, demanding that prospective immigrants should fill in an application form in the English language. The motive behind this was to discourage migrants, who were not of British origin, from migrating to New Zealand. However, at a later stage, it became difficult to enforce and defend this policy. Thus, the Immigration Restriction Amendment Act 1920 was put in place to replace the English language policy and introduce a system of permits for immigrants who were not of British origin, although permanent residence was granted only on the approval of the Minister of Customs (Nayar, 2005). The New Zealand government kept its 'white' policy through assisted migration schemes and entry permits from 1899 until 1987 When the points system was introduced, promoting the selection of immigrants based on merit rather than their country of origin (Nayar, 2005).

Points were awarded for educational, trade or work qualification, family links, command of the English language and the applicant's ability to successfully settle in New Zealand (Ho, Lidgard, Cowling, \& Bedford, 2003). Though migrants to New Zealand continued to be primarily of British origin, the 1960s and 1970s witnessed the arrival of immigrants from the Pacific Islands. In December 1994, Statistics New Zealand recorded 64,380 permanent and long term immigrants residing in New Zealand. By December 2004, this number had increased to 80,480. Among these numerous immigrants to New Zealand, were many from the African continent (Phillips, 2007).

Africa is a vast and varied continent with a huge diversity of cultures and ethnicities. In 2004, there were 44 different African nationalities represented in New Zealand, with most from South Africa, Somalia, Egypt, Zimbabwe and Ethiopia (Phillips, 2007). In the 1970s whites fleeing the Rhodesian war arrived in New Zealand after President Idi Amin mandated that Asian Africans should leave Uganda in 90 days (Phillips, 2007). The adoption of a formal refugee quota in 1987 and the outbreak of wars in countries like Ethiopia, Somalia (and the genocide in Rwanda) resulted in an increase in the number of African refugees arriving in New Zealand. Between 2006 and 2013, according to Statistics New Zealand, the population of the African ethnic group increased from 10, 647 to 13, 464 (Statistics New Zealand, 2013). However, these statistics are controversial because in 2008, the New Zealand Immigration Services (NZIS) estimated that there were 65, 553 Africans in New Zealand with different types of visas: such as limited purpose visas, permanent residency visas, student visas, visitor visas and work visas. In addition, in 2008, the Department of Internal Affairs estimated that there were 25, 796 Africans with New Zealand citizenship. Combining these numbers figures suggests a grand total of 91, 349 Africans living in New Zealand (Tuwe, 2012).

The discrepancy between the census and immigration figures is difficult to understand. However, Tuwe (2012) identified some possible factors that might 
account for the discrepancy. Firstly, the census involves self-reporting and some Africans may have chosen not to indicate that they were from Africa. Secondly, some respondents, who were not born in Africa, may not have reported themselves as African. Thirdly, the majority of Zimbabwean and South Africans living in New Zealand were classified as Europeans in the New Zealand census of 2006. Finally, in the New Zealand 2006 census, Africans from countries like Algeria, Egypt, Libya, Tunisia and Morocco were counted as part of the Middle East and not as Africans. This trend continued in the New Zealand census of 2013, as South Africans are classified separately from other African nations (Statistics New Zealand, 2013).

\section{Method}

This research uses a narrative method based on Africentric philosophy and a unique storytelling tradition that reflects the beliefs, values and rituals of African people in understanding the experiences of African immigrant women migrants. (Mbiti, 1986; Schiele, 2000). The research approach is rooted in the African oral tradition where stories are told in a particular way, putting the focus on some aspects and ignoring others, in order to build an argument or express passion (Mnyandu, 1997). The method lays emphasis on both the content of the story and the form of its telling. The study was approved by the Auckland University of Technology Ethics Committee (AUTEC)

I used a purposive sampling method in selecting participants for this study and conducted individual interviews with fifteen women aged between 21 and 60 years, all of whom were recent migrants from Africa having resided in New Zealand for a period of from one to five years. The main purpose of the interviews was to explore the factors that motivated African women to migrate to New Zealand. There are various African migrant groups in Auckland such as the Nigerian, Ghanaian, Zambian and Zimbabwean communities. For the purpose of gaining access to these women, I had to meet with the community leaders of these communities to inform them of the topic of my research. The community leaders / matriarchs were welcoming of the idea.

Another strategy that I used to recruit participants for the study was distributing fliers that had headings such as, "Are you an indigenous Black African Immigrant woman?". Through the flier I invited women who would like to tell their story. I posted the fliers at African community centres, churches and food shops. I invited African women who would be keen to be part of the research to contact me. I received responses from 21 women. Following the responses from these 21 women, I sent out the participant information sheet to the women.

The findings of the research were analysed based on African theories drawn from Journey in the African Epic and African feminism (Kunene, 1991; Terborg-Penn, 1993). I used some aspects of the "journey motif" that I considered relevant to analyse African women's experiences of immigration. The element that I consider relevant to this article is the Onset of the Journey that explores the reasons why a journey has to be made. This allowed participants in the study to share their experiences of factors that motivated them to migrate to New Zealand.

For the purpose of carrying out the analysis of this study, I have defined story as a process that Africans use to mediate and transmit knowledge and information across generations. In addition, to understand the perspective of the women, I used an African feminist consciousness, one that reflects African women's roles, positioning, strength, and resiliency in striving for the survival of their families and communities. Most often, African 'rural women' are portrayed in scholarly write-ups, and in mass media outlets, as 'likely' to be ignorant, oppressed and poor. As a result of this misrepresentation, African women tend to be described and analysed by those 
who may not understand them or the dynamics of their existence (Maloba, 2007). Likewise, in New Zealand, there are many assumptions and stereotypes about African people and in particular African women. One such stereotype is that they are refugees, uneducated, oppressed by men in their culture and are considered "lucky' to be in New Zealand. It is important to analyse the women's stories through the interpretive lens of their position in their cultures and the dynamics of their lives.

\section{Findings}

The participants in this study shared stories about the factors that motivated them to migrate to New Zealand. From an analysis of the women's stories a variety of motivations emerged. Kunene's (1991) Journey in the African Epic offers a relevant perspective from within which to consider the women's stories. Ordinarily, the hero within the African epic does not need to embark on a journey, but because he is confronted by challenges and measures taken to resolve the challenges do not help him overcome the situation, hence there is a need for him to go on an exile, assuming that embarking on this journey would enable him to gain the needed skill to overcome the challenges.

The five themes that emerged as factors that motivated the participants to come to New Zealand are: political instability, economic reasons, education, social and cultural reasons, and the need for professional development.

\section{Political Instability}

The political situation in their home country was a major motivating factor for some of the women. One participant spoke extensively about the political situation in her country. Her storyline starts with a description of the contented and stable life that she and her family had in Zimbabwe, before major political and economic changes ruptured this stability. Prior to the disruption there was no indication in her story that she felt an urge or need to leave her home. Political instability, and her families changed circumstances, was the turning point that triggered her decision to leave. This participant's narrative reflected the difficulty she experienced in coming to terms with these new circumstances.

I just found the situation; the socioeconomic and political situation in my country was deteriorating at that time. I had also just given birth... and I just needed to see that there's a hope in the future for my children; so with the political situation in my country, I found it really hard from the outlook. (Participant\#10)

The upbeat and optimistic tone used to portray herself prior to the political instability altered when she started sharing her experiences of the political chaos in her country. She presented herself and her children as victims of political, social and economic deterioration. She noted that as a result of political instability, there was no hope in the future for her children and concluded that she found this experience hard to understand. The political conflict in most African countries is associated with economic crises. Two of the participants talked about their experiences with economic crises in their countries and linked this experience to political instability.

\section{The economy}

The political situation in most African countries impacts on other facets of life, such as the economic opportunities available to citizens. Economic instability, inflation and the subsequent adverse effect on employment, led to untold hardship for the women in this study, and for their families. To resolve their economic predicament, most African countries have put some policy measures in place, such as the Structural Adjustment Programme (SAP) in Nigeria, Zambia and Zimbabwe. However, these measures have not resolved the problems. The failure of SAP in most African countries has resulted in a loss of jobs and economic 
opportunities for the majority of families. Some of the women in the study who had been employed in statutory and nonstatutory settings, were pushed on to informal sectors, such as trading in market places both locally and across borders (Maloba, 2007). The women had to come to terms with the challenges of this transition.

The women in the study noted that they chose to migrate to New Zealand because the burden of economic hardship was taking a toll on them. Two of the participants, included this theme as a significant part of their story-line.

Another participant, narrated the situation that led to her migration.

What motivated me to come to New Zealand was the declining economy in my country, Zimbabwe. I struggled; I had teenage children and ... little children, and I was seeing no future for my children in terms of education. In terms of future employment prospects the competition was very high. It was difficult to get my children into good schools. There was a lot of corruption and so you know I didn't see a space for me and my children and so for the sake of my children I decided to come to New Zealand to give them a better future. (Participant \#3)

Participant \#6 talked about the competition and corruption that loomed large in her country encroaching on the future life chances for her children. Despite the good life that this participant had had, she felt she had to make the needs and future of her children a priority and to migrate leaving nearly everything behind. Her narrative is typical of many African women representing the essence of African womanhood in making sacrifices for the survival of their children (Schmidt, 1992). That she could make the decision to resolve this conflict also reflects the complementary role of African women to African masculinity in making decisions paramount to the continuity and survival of African families (Terborg-penn, 1996).

Traditionally, African women are expected to work outside the home to fulfil their economic role and ensure the complementary role between them and their men (House-Midamba \& Ekechi, 1995; Sudarkasa, 1987; Terborg-penn, 1996). During the pre-colonial era, social and economic production was centred on women (Amadiume, 2005; Strobel, 1982). However, this complementary nature of the respective roles appears to have been ignored by some scholars; with men being ascribed a better and higher status, while women are portrayed as being "saddled with home and domesticity" (Sudarkasa, 2004, p. 73). African feminists have challenged this notion that women were outside the home working as well as embracing domesticity. There was no time in history that African women did not fulfil their economic role to complement their men.

Participant \#13, talked about the introduction of the Structural Adjustment Programme (SAP) and its impact on the social and economic situation in Zimbabwe. She narrated:
Programme ESAP, we call it ESAP, had been started in 1990 and 10 years later in 2000 it had got just worse and worse with the government introduced this, they said to us that it was going to be a temporary measure, we were going to fasten our belts but would soon be undoing them when things got better but instead the situation got worse and worse and worse.

Instead of the promise of 'hope' that things would improve after a few years of the programme, the evaluation of the impact by the participant was that "it got just worse and worse". Maloba (2007) identified the impact of ESAP on women in Africa, and concluded that ESAP did not address what it was designed to achieve; rather, it increased barriers to women's entry into higher paying and economically rewarding enterprises. African women experienced 
reduced mobility because they were forced to "use their working capital to cover the rising cost of basic family needs such as food, health expenses and school fees" (Maloba, 2007 , p. 219). She concluded that poverty and the need to provide for their families drove many women into the informal sector, such as trading. Although, participants \#6 and \#13 were not pushed into the informal sectors (trading), they had to make life changing decisions regarding the fulfilment of their traditional roles, which involved migrating to New Zealand. They used their narratives to inscribe their identities (Daslyva, 2007) as mothers who needed to see a future for their children and ensure the survival of their family members.

The aftermath of conflicts at home, such as political and socio-economic deterioration in some African countries, has had a negative impact on the education sector. The women noted that there is no guarantee of young ones gaining admission to higher learning institutions because of stiff competition and limited resources. The goal of achieving a quality education with internationally recognised qualification for themselves, their spouses and children was a motivation for some of the women to migrate.

\section{Education}

Nunya adidoe asimetune o (knowledge is like a baobab tree, you cannot embrace it with your arms alone. (African proverb)

Most participants in the study highlighted the deteriorating education systems in their home countries as a reason for migration. Some of them migrated to join their spouses who were studying in New Zealand as international students. The women wove the theme of education throughout the narratives that they shared. Participant \#9 told of the importance of education for her children, and its future benefits, as a reason that motivated her to migrate:

I knew that even if my children walk naked they've got their education; they've got the tools they need. I'll use the analogy of in a village where there has been drought; the rain doesn't come that person with the tools the person with the hoe and the plough and the day it rains he runs to the fields and starts to work on the on the land but that person without the tools you're going to start thinking ok maybe I'll go now into town and go and buy that hoe to go and buy to sow them and he never had them in the first place. That is what I put as the education; the personal education once it rains once the jobs are available they go out to get their jobs. So I always want my children to have education even though even if the jobs not available but they should have them the education to secure them.

Africans hold education in high esteem. It was clear from the narratives of the women, that education is considered as a tool to improve one's future; thus, the women sacrificed immensely for their families, children and husbands, in order to gain qualifications that would be useful in the future. They used their narratives to describe themselves as knowledgeable and articulate about their goals; as evidenced by the statements and the actions that they took to ensure quality education for themselves, their spouses and children. Another reason identified as a motivating factor for African women migrating to New Zealand is the influence of their friends and family members.

\section{Friends and family}

The importance of friends and family as motivating factors for migration cannot be over-emphasised. Some of the women indicated that they had previous knowledge of New Zealand because of New Zealand friends; while others were invited to New Zealand by their husbands or parents. (Participant \#3) talked about her experience:

Ok, in the first place my husband came here first and we got married. I was living in Ghana so probably it was going to be 
a bit harder if I were to live in Ghana and he was to live in New Zealand; so we thought that it would be very, very important for the two of us to live together. He applied and then I decided to come and join him over here and to begin life. So that was the main reason for coming to New Zealand.

Her story was around the need to live together with her husband. She repeated this statement and said that it really mattered to her, which shows the importance she placed on the two of them living together. Anika, the youngest of the women, was 28 years at the time of the interview; she came to New Zealand to join her parents who had been in New Zealand for 10 years:

I came here because my parents were here; my dad has been here for 10 years and mum has been here for nearly 8 years.

The women's narratives reflected optimism and confidence in discussing the social factors that motivated them to migrate to New Zealand. Another reason motivating factor for the African women in this study was access to professional development.

\section{Professional development}

Three of the participants, migrated to practise as nurses. Of the 15 women interviewed, only these three women were able to find employment in their field of practice. Participant \#12 had been practising as a nurse in Europe before securing a job with a nursing agency in New Zealand. Participant\#11 had received information on nursing practice from her brother; and she had migrated, claiming that she had sorted out her paper work with the New Zealand Nursing Council before migrating. She positioned herself as someone that came to practice nursing and to have "fun": "The first reason was to come here to practise nursing, and secondly, for the purpose of adventure". Participant \#15, on the other hand, positioned herself as a nurse who was in high demand.
My profession is nursing and you know we are needed everywhere in the world. So before I came to New Zealand, I got a job offer which was through an agency; so I came here with the job which was a bonus on my own part, because it was difficult for a lot of people to get permanent jobs. This position wasn't a problem for me at all. It took me 2 months from after I arrived here; hence I worked for agencies during that period.

This is a counter narrative to other African women in this study. Unlike the other women, she did not migrate directly to New Zealand from Africa, but she had come via Malta (in Europe). Amongst the pull factors for nurses migrating to developed countries are: higher wages, better living and working conditions and opportunities for advancing their education and expertise. Although the three women had not presented reasons for migrating beyond the story shared the above motivating factors cannot be ruled out.

Unlike the period when migration from Africa was dominated by men, the women shared stories of migration in order to secure educational and economic opportunities for their children, and to access opportunities for professional development. The women presented themselves as active in decisions regarding their migration. Their narratives reflect a view of themselves as active agents, making choices to achieve the social, political, economic, and cultural survival of their community (Acholonu, 1995).

The narratives of the women challenge the notion that African women are powerless and dominated by the men in their culture. Their narratives reflected an overlap rather than a dichotomy between the public and the private arena. Sudarkasa (1996) supports this point, noting that in pre-capitalist African societies this dichotomy does not correspond to masculine and feminine domains as most Western feminist theories argue. The narratives shared by the women indicate that they were active outside the home, as well as in it. 


\section{Conclusion}

The narratives of the women in this article reflected optimism and confidence in discussing the factors that motivated them to migrate to New Zealand. Most participants were faced with challenges in their home countries, challenges that threatened their identity and livelihood, and that of their families. Migration to New Zealand was considered as a positive move to overcome these challenges, and to access the opportunities and skills they needed for their survival and the survival of their families. The stories narrated also reflect the importance of the support system of family and friends in African women's migration journeys to New Zealand.

The rapid growth of new immigrant populations, and the increasing cultural diversity of the New Zealand population, will continue to have important implications for the social work profession. Taking into consideration the core competence standards required for social workers in Aotearoa New Zealand we need to ensure that social workers are trained and educated to become culturally competent to work with new migrants. This will include developing an appreciative understanding of the culture and history of new migrants, but also an appreciation of their aspirations and motivations for setting out on a journey that represents a huge transition for them and for their families.

\section{References}

Acholonu, C. (1995). Motherism: the Afrocentric alternative to feminism. Owerri, Nigeria: Afa Publications.

Amadiume, I. (2005). Women and development in Africa. Retrieved from http://www.sgiquarterly.org/ feature2005Jan-3.htm

Bhugra, D. (2003). Migration and depression. Acta Psychiatrica Scandinavica, 108(Suppl. 418), 67-72.

Fletcher, M. (1999). Migrant settlement: $A$ review of the literature and its relevance to New Zealand. Wellington, New Zealand: Department of Labour. Retrieved from http://www.mbie. govt.nz/publications-research/research/migrants--settlement/MigrantSettlementLiteratureReviewSept-1999.pdf

Henderson, A. (2004). The Settlement experiences of immigrants (excluding refugees) in New Zealand: An overview paper completed for the Auckland Regional Settlement Strategy. Retrieved from http://www.immigration.govt.nz/NR/rdonlyres/ D9BA1C72-E6BA-4C6C-A8FD-66373D55C3E2/0/ MigrantLiteratureOverview.pdf
Ho, E.S., Lidgard, J.M., Cowling, W.E., \& Bedford, R.D. (2003). Knowledge for new settlers: A survey of needs in Hamilton. Hamilton, New Zealand: Migration Research Group and Anthropology Department, University of Waikato. Retrieved from http://www.waikato.ac.nz/_data/assets/ pdf_file/0011/76556/project03-newsettlers.pdf

House-Midamba, B., \& Ekechi, F. K. (1995). African market women and economic power: The role of women in African economic development. Connecticut, London: Greenwood Press.

Kunene, D. P. (1991). Journey in the African epic. Research in African Literatures, 22(2), 205-223.

Maloba, W. (2007). African women in revolution. Trenton, NJ: Africa World Press.

Mbiti, J. (1969). African religions and philosophy. London, United Kingdom: Heineman

Mnyandu, M. (1997). Ubuntu as the basis of authentic humanity: An African perspective. Journal of Constructive Theology, 3(1), 77-91.

Nayar, S. (2005). Two becoming one: Immigrant Indian women sustaining self and well-being through doing. Masters Thesis, Auckland University of Technology, Auckland.

Ngo, H. (1994). The economic role of immigrant wives in Hong Kong. International migration, 32(3), 403-423.

Phillips, J. (2007, 9 January). History of immigration. Retrieved from http://www.teara.govt.nz/en/history-ofimmigration

Reynolds, R. (2006). Professional Nigerian women, household economy, and migration decisions. International Migration, 44(5), 167-188.

Statistics New Zealand. (2006). The 2006 New Zealand Census. Retrieved from http://www.stats.govt.nz/ Census/2006CensusHomePage.aspx

Statistics New Zealand. (2013). The 2013 New Zealand Census. Retrieved from http://www.stats.govt.nz/ Census/2013CensusHomePage.aspx

Strobel, M. (1982). African women. Signs: Journal of Women in Culture and Society, 8(1), 109-131.

Sudarkasa, N., \&. (1996). The strength of our mothers: African and African American women and families: essays and speeches. Trenton, New Jersey: African World Press.

Schmidt, E. (1992). Peasants, traders, and wives: Shona women in the history of Zimbabwe, 1870-1939. Portsmouth, NH: Heinemann.

Schiele, J. (2000). Human services and the Afrocentric paradigm. New York, USA: Haworth Press.

Terborg-penn, T., \& Rushing, A. B. (1996). African feminsim: A theoretical Approach to the History of Women in the African Diaspora. Washington D.C: Howard University press.

Triln, A.D. (1992). Change and continuity: New Zealand's immigration policy in the late 1980s. In A.D. Trlin \& $P$. Spoonley (Eds.), New Zealand and International Migration: A Digest and Bibliography, No. 2. Palmerston North, New Zealand: Massey University.

Tuwe, K. (2012). The challenges of health promotion within African communities in New Zealand. Masters of Philosophy Thesis, Auckland University of Technology, Auckland. 